\title{
Spotlight on brexpiprazole and its potential in the treatment of schizophrenia and as adjunctive therapy for the treatment of major depression
}

This article was published in the following Dove Press journal:

Drug Design, Development and Therapy

II May 2016

Number of times this article has been viewed

\section{Dawn Bruijnzeel \\ Rajiv Tandon}

Department of Psychiatry, University of Florida College of Medicine, Gainesville, FL, USA
Correspondence: Dawn Bruijnzeel Department of Psychiatry, University of Florida College of Medicine, I60I SW Archer Rd, II6A, Gainesville, FL 32608, USA

Tel +I 352376 I6II ext 438I

Email dheron@ufl.edu
Abstract: Antipsychotic agents, utilized for the treatment of a range of psychiatric disorders, differ substantially in terms of their pharmacology and adverse effect profiles. Incomplete and variable efficacy, differences in safety-tolerability, and highly heterogeneous response across individuals prompt development of new agents. Brexpiprazole is one of the two most recently introduced antipsychotic agents approved for the treatment of schizophrenia and as an adjunct for treatment of major depressive disorder. Its pharmacology, clinical trial data, and efficacy and side effects in comparison with other antipsychotic agents are discussed. Brexpiprazole is a dopamine D-2 partial agonist with potent activity at the serotonin $5 \mathrm{HT}_{1 \mathrm{~A}}$ and $5 \mathrm{HT}_{2 \mathrm{~A}}$ and noradrenergic alpha-1B and alpha- $2 \mathrm{C}$ receptors. Placebo-controlled clinical trials in persons with schizophrenia support its efficacy in treating psychosis and preventing relapse. Shortterm clinical trials also support its efficacy as an adjunct to antidepressants in treating major depressive disorder in individuals inadequately responsive to antidepressant treatment alone. Adverse effects include akathisia, gastrointestinal side effects, and moderate weight gain. The recommended oral dose of brexpiprazole is $2-4 \mathrm{mg}$ /day in schizophrenia and $2-3 \mathrm{mg}$ /day as adjunctive treatment in major depression. It must be titrated up to its target dose over 1-2 weeks and is effective in once-daily dosing. How brexpiprazole's unique pharmacological profile will translate into clinically meaningful differences from other antipsychotic agents is unclear. Its place in our antipsychotic armamentarium and potential role in the treatment of schizophrenia and major depressive disorder will be determined by additional clinical data and experience.

Keywords: brexpiprazole, partial agonist, schizophrenia, major depression, treatment, pharmacology, dopamine

\section{Introduction}

Twenty antipsychotic medications are currently approved for clinical use in the US (Figure 1) with brexpiprazole (Rexulti ${ }^{\circledR}$ ) being one of the most recent agents to become available. Despite the availability of a number of antipsychotic medications, many patients either do not benefit from or develop significant side effects to currently available agents. ${ }^{1}$ In this article, we review the pharmacological profile of brexpiprazole, summarize clinical trial data that pertain to its efficacy and safety-tolerability, discuss its optimal clinical utilization, compare its clinical profile to that of other commonly used antipsychotic agents, and critically evaluate its potential role in the treatment of schizophrenia and major depressive disorder. 


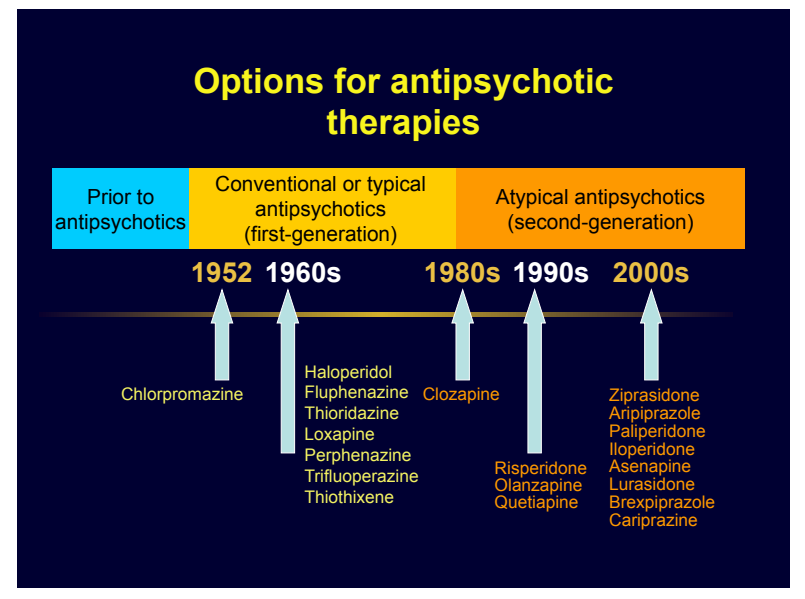

Figure I Antipsychotic agents in the USA.

\section{Receptor pharmacology}

Brexpiprazole is a phenylpiperazine derivative whose unique chemical structure most closely resembles aripiprazole among currently available antipsychotic agents. ${ }^{2}$ In the scheme of broadly classifying antipsychotic agents into first-generation and second-generation antipsychotics (SGAs), brexpiprazole is an SGA. ${ }^{3}$ Like other antipsychotic agents, the precise mechanism of antipsychotic action of brexpiprazole is currently unknown, although it appears to be related to its activity at the dopamine $\mathrm{D}_{2}$ receptor. ${ }^{4}$ Brexpiprazole is a partial agonist at the dopamine $\mathrm{D}_{2}$ receptor, similar to aripiprazole and cariprazine. It also shares the additional attribute shared by all currently available SGAs - the ability to potently block the serotonin $5 \mathrm{HT}_{2 \mathrm{~A}}$ receptor. ${ }^{2,5}$ Additionally, brexpiprazole has potent activity at the serotonin $5 \mathrm{HT}_{1 \mathrm{~A}}$ (partial agonist) and noradrenergic alpha-1 and alpha-2 (antagonist) receptors. ${ }^{2}$ It exhibits moderate antagonist activity at the serotonin $5 \mathrm{HT}_{7}$ and $5 \mathrm{HT}_{2 \mathrm{C}}$ and histamine $\mathrm{H}_{1}$ receptors and negligible activity at the muscarinic cholinergic $\mathrm{M}_{1}$ receptor.

A comparison of brexpiprazole's receptor binding profile with that of aripiprazole is instructive. Whereas both aripiprazole and brexpiprazole are high-affinity, partial agonists at the dopamine $\mathrm{D}_{2}$ receptor, brexpiprazole has twice the affinity and approximately half the intrinsic activity of aripiprazole at this receptor. Brexpiprazole has higher affinity to and greater intrinsic activity than aripiprazole at the serotonin $5 \mathrm{HT}_{1 \mathrm{~A}}$ receptor, where both agents are partial agonists. In contrast to aripiprazole, brexpiprazole has significantly greater antagonist activity at alpha-1a and alpha-2 noradrenergic receptors.

Although the precise clinical implications of this pharmacological profile are not fully known, current understanding of potential efficacy and side effect consequences of relevant neurotransmitter receptor modulation is summarized in
Table $1 .^{6}$ The potent $\mathrm{D}_{2}$ affinity with low intrinsic activity (likely functional antagonism in the mesolimbic dopamine system) along with potent $5 \mathrm{HT}_{2 \mathrm{~A}}$ antagonism might appear to confer upon brexpiprazole the attribute of a potent antipsychotic with low liability to cause extrapyramidal side effects - as with other SGAs. The lower intrinsic activity at the dopamine $\mathrm{D}_{2}$ receptor, in comparison to aripiprazole, positions brexpiprazole in between that agent and other antipsychotics (which are $\mathrm{D}_{2}$ antagonists with $0 \%$ intrinsic activity) in this regard. The potent $5 \mathrm{HT}_{1 \mathrm{~A}}$ partial agonism and moderate $5 \mathrm{HT}_{7}$ antagonism could potentially be associated with improved cognition and antidepressant benefits; ${ }^{7-10}$ whereas the potent alpha-1 and alpha-2 noradrenergic antagonism could contribute to hypotension and necessitate gradual titration to a target dose. The enhancement of noradrenergic neurotransmission in conjunction with $5 \mathrm{HT}_{2 \mathrm{~A}}$ antagonism may contribute to its antidepressant effects. The absence of significant affinity to the $M_{1}$ receptors suggests a low liability for this agent to cause peripheral and central anticholinergic side effects, ${ }^{11}$ whereas the low affinity at the $\mathrm{H}_{1}$ and $5 \mathrm{HT}_{2 \mathrm{C}}$ receptors suggests a modest potential for weight gain and other metabolic side effects. Data from preclinical studies with brexpiprazole have generally been consistent with this profile.

\section{Pharmacokinetics}

The activity of brexpiprazole is almost exclusively due to the parent drug. The pharmacokinetics of brexpiprazole is dose-proportional within a total daily dose of $1-8 \mathrm{mg}$ and steady-state concentrations are reached within 2 weeks. The mean half-life at steady-state is $\sim 91$ hours. ${ }^{12}$ Brexpiprazole is rapidly absorbed after oral administration, reaching peak serum concentrations in 4 hours. Approximately $95 \%$ is absorbed without any notable impact of food. Brexpiprazole is highly protein-bound (over 99\%), with high affinity for alpha- 1 glycoprotein and albumin. Protein binding is not affected by hepatic or renal impairment. Brexpiprazole is eliminated largely by hepatic metabolism, principally via cytochrome P450 (CYP)-3A4 and -2D6. Thus, drugs that induce or inhibit the CYP-3A4 enzyme system may have profound effects on its bioavailability. In contrast, brexpiprazole is neither an inducer nor inhibitor of CYP enzymes. It has one major inactive metabolite (DM-3411). Less than $1 \%$ is excreted unchanged in the urine.

\section{Clinical trials in schizophrenia Focus on efficacy}

Data on the short-term efficacy and safety of brexpiprazole in the treatment of schizophrenia are available from three 
Table I Clinical implications of agonism and antagonism at various neurotransmitter receptors

\begin{tabular}{|c|c|c|}
\hline Receptor and activity & Benefits & Side effects \\
\hline \multicolumn{3}{|l|}{ Dopamine receptors } \\
\hline $\mathrm{D}_{2}$ receptor & Antipsychotic effects & Extrapyramidal side effects (EPS): \\
\hline \multirow[t]{11}{*}{ (antagonist) } & Efficacious for positive symptoms & Dystonia \\
\hline & & Parkinsonism \\
\hline & & Tardive dyskinesia \\
\hline & & Prolactin elevation: \\
\hline & & Galactorrhea \\
\hline & & Gynecomastia \\
\hline & & Menstrual changes \\
\hline & & Sexual dysfunction \\
\hline & & Negative symptoms \\
\hline & & Cognitive dysfunction \\
\hline & & Dysphoria \\
\hline \multicolumn{3}{|l|}{ Serotonin receptors } \\
\hline $5 \mathrm{HT}_{\mathrm{IA}}$ & Possible improved mood & Not known \\
\hline (agonist) & Possible improved cognition & \\
\hline $\begin{array}{l}5 \mathrm{HT}_{2 \mathrm{~A}} \\
\text { (antagonist) }\end{array}$ & Reduced EPS & Not known \\
\hline $\begin{array}{l}5 \mathrm{HT}_{2 \mathrm{C}} \\
\text { (antagonist) }\end{array}$ & Not known & Weight gain \\
\hline $5 \mathrm{HT}_{7}$ & Possible efficacy in improving mood & Not known \\
\hline (antagonist) & Possible efficacy in improving cognition & \\
\hline \multicolumn{3}{|l|}{ Adrenergic receptors } \\
\hline$\alpha_{1}$ & Not known & Postural hypotension \\
\hline (antagonist) & & Dizziness \\
\hline & Not known & Changes in blood pressure \\
\hline (antagonist) & & Possible hyperalgesia \\
\hline \multicolumn{3}{|l|}{ Histamine receptors } \\
\hline $\mathrm{H}_{1}$ & Not known & Sedation \\
\hline (antagonist) & & Weight gain \\
\hline \multicolumn{3}{|l|}{ Acetylcholine receptors } \\
\hline \multirow[t]{6}{*}{ Muscarinic } & Not known & Blurred vision \\
\hline & & Xerostomia \\
\hline & & Constipation \\
\hline & & Urinary retention \\
\hline & & Sinus tachycardia \\
\hline & & Cognitive dysfunction \\
\hline
\end{tabular}

6-week, Phase II or Phase III double-blind, randomized, placebo-controlled multinational, multicenter clinical trials in 1,769 patients (Table 2). ${ }^{13-15}$ The average age of patients in these studies was 40 years, with two-thirds being male, and patients had a moderately severe illness burden at baseline on average. One of these three studies also included an active antipsychotic comparator (ie, aripiprazole). ${ }^{13}$ This particular study was a failed study in that neither brexpiprazole $(0.25,1,2.5$, and $5 \mathrm{mg} /$ day) nor aripiprazole (15 $\mathrm{mg} /$ day) was found to be more effective than placebo. ${ }^{13}$ In the other two studies, 2-4 mg of brexpiprazole was found to be more effective than placebo. While preliminary data suggest that the $4 \mathrm{mg} /$ day dose may be more efficacious than the $2 \mathrm{mg}$ daily dose, this is not definitive. ${ }^{14,15}$ Consequently, it is recommended that $2 \mathrm{mg}$ /day be the initial target dose of brexpiprazole with gradual titration up to this dose and $4 \mathrm{mg} /$ day the maximum recommended dose. ${ }^{12}$ In these studies, brexpiprazole was found to be effective across multiple dimensions of schizophrenia. ${ }^{16}$

Brexpiprazole (up to $4 \mathrm{mg} /$ day) has also been compared to quetiapine extended release (up to $800 \mathrm{mg} /$ day) and placebo in 465 patients with an acute exacerbation of schizophrenia in a 6-week randomized clinical trial (NCT01810380), but results of this study are currently unavailable.

The long-term efficacy of brexpiprazole has been evaluated in a 1-year double-blind, placebo-controlled maintenance study of 202 schizophrenia patients. ${ }^{17}$ The stabilization and medication-withdrawal study design is currently the 
Table 2 Acute placebo-controlled clinical trials of brexpiprazole in the treatment of schizophrenia

\begin{tabular}{|c|c|c|c|c|}
\hline Study & $\begin{array}{l}\text { Study duration } \\
\text { number of patients }\end{array}$ & $\begin{array}{l}\text { Daily dose of } \\
\text { brexpiprazole }\end{array}$ & Comparator & Findings \\
\hline McQuade et $\mathrm{al}^{13}$ & $\begin{array}{l}6 \text { weeks } \\
459 \text { patients }\end{array}$ & $\begin{array}{l}0.25 \mathrm{mg} \\
1 \mathrm{mg} \\
2.5 \mathrm{mg} \\
5 \mathrm{mg}\end{array}$ & $\begin{array}{l}\text { Placebo } \\
\text { aripiprazole } 15 \mathrm{mg}\end{array}$ & $\begin{array}{l}\text { Failed study } \\
\text { Neither aripiprazole nor any dose of } \\
\text { brexpiprazole found to be more effective than } \\
\text { placebo }\end{array}$ \\
\hline Correll et al ${ }^{14}$ & $\begin{array}{l}6 \text { weeks } \\
353 \text { patients }\end{array}$ & $\begin{array}{l}0.25 \mathrm{mg} \\
2 \mathrm{mg} \\
4 \mathrm{mg}\end{array}$ & Placebo & $\begin{array}{l}\text { Both } 2 \text { and } 4 \mathrm{mg} \text { of brexpiprazole found } \\
\text { significantly more effective than placebo in overall } \\
\text { psychopathology (PANSS and CGI), positive, and } \\
\text { negative symptoms }\end{array}$ \\
\hline Kane et al ${ }^{15}$ & $\begin{array}{l}6 \text { weeks } \\
674 \text { patients }\end{array}$ & $\begin{array}{l}1 \mathrm{mg} \\
2 \mathrm{mg} \\
4 \mathrm{mg}\end{array}$ & Placebo & $\begin{array}{l}4 \mathrm{mg} \text { brexpiprazole, but not I or } 2 \mathrm{mg} \text {, was } \\
\text { significantly more effective than placebo in overall } \\
\text { psychopathology (PANSS and CGI), positive, and } \\
\text { negative symptoms }\end{array}$ \\
\hline Hobart et al ${ }^{17}$ & $\begin{array}{l}52 \text { weeks } \\
202 \text { patients }\end{array}$ & $\mathrm{I}-4 \mathrm{mg} /$ day & Placebo & $\begin{array}{l}\text { Brexpiprazole more effective than placebo in } \\
\text { relapse prevention with significantly delayed time } \\
\text { to relapse and lower rate of relapse }\end{array}$ \\
\hline
\end{tabular}

Abbreviations: PANSS, positive and negative syndrome scale; CGI, clinical global impression.

standard for the evaluation of the effectiveness of treatments in preventing relapse in schizophrenia. ${ }^{18}$ Brexpiprazole was found to be significantly more effective than placebo in preventing relapse, with a significantly lower proportion of schizophrenia patients relapsing in the brexpiprazole versus placebo group $(13.5 \%$ vs $38.5 \%, P<0.01)$ over the 1 -year period.

Brexpiprazole at doses between 2 and $4 \mathrm{mg}$ /day has thus far been efficacious in the treatment of schizophrenia in several short-term studies. How its efficacy compares to that of other antipsychotic agents is unclear. Only limited data are currently available from head-to-head clinical trials, and final results of the completed study comparing brexpiprazole to quetiapine are not yet available. The hope that brexpiprazole might offer advantages in treating the cognitive symptoms of schizophrenia, based on its potent serotonin $5 \mathrm{HT}_{1 \mathrm{~A}}$ partial agonism and $5 \mathrm{HT}_{2 \mathrm{~A}}$ and $5 \mathrm{HT}_{7}$ antagonism, awaits confirmation in clinical trials - current data are inadequate to support the claim. ${ }^{19,20}$ Similarly, the promise that brexpiprazole might more effectively treat the mood symptoms of schizophrenia (again based on its distinctive pharmacological profile) awaits confirmation in clinical trials.

\section{Adverse events and safety-tolerability}

Data on the safety-tolerability of brexpiprazole in the treatment of schizophrenia were also compiled from the studies discussed earlier. Dose-dependent side effects of brexpiprazole include nausea, akathisia, headache, and modest weight gain. In contrast to aripiprazole that reduces prolactin levels, modest dose-dependent increases in prolactin levels are observed with brexpiprazole. This difference is likely explained by the lower intrinsic activity of brexpiprazole versus aripiprazole at the dopamine $\mathrm{D}_{2}$ receptor, rendering brexpiprazole intermediate between aripiprazole and other antipsychotic agents in this regard. Although a modestly greater weight gain was also observed, no significant differences from placebo were observed with regard to changes in serum glucose or lipids. Lastly, this agent appears to have little effect on the corrected QT interval on electrocardiogram.

There are several class level warnings included in the product label for brexpiprazole. These include increased mortality in elderly patients with dementia-related psychosis (black box), cerebrovascular adverse reactions, including stroke, neuroleptic malignant syndrome, tardive dyskinesia, hyperglycemia, dyslipidemia, hyperprolactinemia, leukopenia, seizures, orthostatic hypotension, potential for cognitive impairment, disrupted body temperature regulation, and dysphagia.

In the absence of direct head-to-head trials versus other antipsychotic agents, it is difficult to precisely place brexpiprazole in the context of other available antipsychotic agents in terms of its adverse effect profile. It appears intermediate between aripiprazole and other SGAs, with a relatively low occurrence of metabolic side effects and modest rates of akathisia. Results of the comparator trials should provide greater clarity.

\section{Clinical trials in major depressive disorder \\ Focus on efficacy}

The short-term efficacy and safety of brexpiprazole in the treatment of major depressive disorder have been assessed in 
Table 3 Acute placebo-controlled clinical trials of adjunctive brexpiprazole in the treatment of major depressive disorder inadequately responsive to antidepressant alone

\begin{tabular}{|c|c|c|c|c|}
\hline Study & $\begin{array}{l}\text { Study duration } \\
\text { number of patients }\end{array}$ & $\begin{array}{l}\text { Daily dose of brexpiprazole } \\
\text { antidepressant }\end{array}$ & $\begin{array}{l}\text { Comparator } \\
\text { antidepressant }\end{array}$ & Findings \\
\hline Thase et $\mathrm{a}^{21}$ & $\begin{array}{l}6 \text { weeks } \\
429 \text { patients }\end{array}$ & $\begin{array}{l}0.15 \mathrm{mg} \\
0.5 \mathrm{mg} \\
1.5 \mathrm{mg}\end{array}$ & Placebo & $\begin{array}{l}\text { I.5 mg, but not other doses of } \\
\text { brexpiprazole found to be more effective } \\
\text { than placebo in antidepressant response }\end{array}$ \\
\hline Thase et $\mathrm{a}^{22}$ & $\begin{array}{l}6 \text { weeks } \\
379 \text { patients }\end{array}$ & $2 \mathrm{mg}$ & Placebo & $\begin{array}{l}2 \mathrm{mg} \text { of brexpiprazole found significantly } \\
\text { more effective than placebo as adjunctive } \\
\text { treatment to antidepressant }\end{array}$ \\
\hline Thase et $\mathrm{a}^{23}$ & $\begin{array}{l}6 \text { weeks } \\
677 \text { patients }\end{array}$ & $\begin{array}{l}1 \mathrm{mg} \\
3 \mathrm{mg}\end{array}$ & Placebo & $\begin{array}{l}3 \mathrm{mg} \text {, but not I mg, brexpiprazole, } \\
\text { significantly more effective than placebo in } \\
\text { improving depression }\end{array}$ \\
\hline
\end{tabular}

three 6-week, Phase II or Phase III double-blind, randomized, placebo-controlled multinational, multicenter clinical trials in $\sim 1,500$ patients (Table 3 ). ${ }^{21-23}$ The average age of patients in these studies was 45 years, with approximately a third being male, and study participants had moderately severe illness burden at baseline (average Montgomery-Asberg Depression Rating Scale total score $=26) .{ }^{24}$ In all three studies, patients with major depressive disorder with inadequate response to one to three trials of standard antidepressant medications were selected and received an 8-week prospective trial of a standard antidepressant + placebo. Those who did not respond to such treatment were then randomized to receive adjunctive brexpiprazole or placebo for 6 weeks. In these studies, treatment with $1.5-3 \mathrm{mg}$ of adjunctive brexpiprazole/day was found to produce significantly greater reduction in total MontgomeryAsberg Depression Rating Scale scores (the primary outcome measure $)^{25}$ and a greater proportion of improved patients than adjunctive placebo. Consequently, it is recommended that 1.5-2 mg/day be the initial target dose of adjunctive brexpiprazole with gradual titration up to this dose and $3 \mathrm{mg} /$ day is the maximum recommended dose for this indication. ${ }^{12}$

The extent of improvement observed with brexpiprazole augmentation of antidepressant is similar in magnitude to that observed in studies of aripiprazole ${ }^{25,26}$ and quetiapine ${ }^{27}$ augmentation.

\section{Adverse events and safety-tolerability}

Data on the safety-tolerability of brexpiprazole as an adjunctive treatment of major depressive disorder were also compiled from the studies discussed earlier. Short-term side effects of brexpiprazole include nausea, diarrhea, akathisia, and modest weight gain. Long-term safety-tolerability data were derived from over 2,000 patients with major depressive disorder who received brexpiprazole augmentation. ${ }^{28}$ Moderate weight gain was noted as the major adverse effect.

\section{Clinical use}

Brexpiprazole is currently approved by the US Food and Drug Administration for the treatment of schizophrenia and as adjunctive treatment of major depressive disorder.

The recommended starting dose for major depressive disorder is $0.5 \mathrm{mg}$ /day to be titrated up to $1.0 \mathrm{mg}$ /day and then to the target dose of $2 \mathrm{mg} /$ day with dosage increases to occur at weekly intervals based on patient response and tolerability (hypotension is the main side effect that necessitates gradual titration). The maximum recommended dose for adjunctive treatment of major depressive disorder is $3 \mathrm{mg} /$ day.

The recommended starting dose for schizophrenia is $1 \mathrm{mg}$ /day to be increased to the target dose of $2 \mathrm{mg} /$ day over a week based on patient response and ability to tolerate the drug. The maximum daily dose is $4 \mathrm{mg} /$ day.

Brexpiprazole can be administered once a day and taken with or without food. Dose adjustments are likely unnecessary on the basis of age, sex, or race. Dose adjustment is recommended in the presence of moderate-severe hepatic impairment or moderate-severe renal impairment; in both instances, the daily dose should not exceed $3 \mathrm{mg} / \mathrm{day}$. If brexpiprazole is administered along with strong CYP-2D6 or -3A4 inhibitors, lower doses should be utilized (approximately half the usual dosage); alternatively, if it is administered with strong CYP-3A4 inducers, higher doses should be utilized.

\section{Summary}

Brexpiprazole appears to be a useful addition to our current armamentarium of antipsychotic medications for the treatment of schizophrenia and adjunctive treatment for major depressive disorder that is inadequately responsive to antidepressants alone. It seems comparable to currently available SGAs (ie, similar efficacy, reduced but some extrapyramidal side effect liability) with a relatively low risk of metabolic adverse effects. It should be emphasized, however, that 
long-term data on the use of brexpiprazole in the treatment of schizophrenia and major depressive disorder are sparse at this time. Furthermore, available data directly comparing brexpiprazole to other available antipsychotic agents in head-to-head clinical trials are limited. The putative clinical benefits of brexpiprazole relative to other SGA agents need to be demonstrated in well designed and appropriately powered studies and direct comparative studies have thus far not been conducted. The therapeutic place of brexpiprazole in the treatment of schizophrenia and manic disorder and as an adjunct in major depressive disorder will be determined by additional clinical data and clinical experience.

\section{Disclosure}

The authors report no conflicts of interest in this work.

\section{References}

1. Tandon R. Antipsychotics in the treatment of schizophrenia: an overview. J Clin Psychiatry. 2011;72:1-8.

2. Maeda K, Sugino H, Akazawa H, et al. Brexpiprazole I: in-vitro and in-vivo characterization of a novel serotonin-dopamine activity modulator. J Pharmacol Exp. Ther. 2014;350:589-604.

3. Tandon R, Moller H-J, Belmaker RH, et al. World Psychiatry Association Pharmacopsychiatry Section statement on comparative effectiveness of antipsychotics in the treatment of schizophrenia. Schizophr Res. 2008; 100:20-38.

4. Kapur S, Remington G. Dopamine D2 receptors and their role in antipsychotic action: still necessary and may even be sufficient. Biol Psychiatry. 2001;50:873-883.

5. Oosterhof CA, El Mansari M, Blier P. Acute effects of brexpiprazole on serotonin, dopamine, and norepinephrine systems: an in-vivo electrophysiologic characterization. J Pharmacol Exp Ther. 2014;351: 585-595.

6. Tandon R, Nasrallah HA, Keshavan MS. Schizophrenia, "Just the facts" 5. Treatment and prevention. Schizophr Res. 2010;122:1-23.

7. Yoshimi N, Fujita Y, Ohgi Y, Futamura T, Kikuchi T, Hashimoto K. Effects of brexpiprazole, a novel serotonin-dopamine modulator, on phencyclidine-induced cognitive deficits in mice: a role for $5 \mathrm{HT}_{1 \mathrm{~A}}$ receptors. Pharmacol Biochem Behav. 2014;124:245-249.

8. Ishima T, Futamura T, Ohgi Y, Yoshimi N, Kikuchi T, Hashimoto K. Potentiation of neurite growth by brexpiprazole, a novel serotonindopamine activity modulator. Eur Neuropsychopharmaol. 2015;25: $506-511$.

9. Himmeloch S, Taylor SF, Goldman RS, Tandon R. Frontal lobe tasks, antipsychotic medication, and schizophrenia syndromes. Biol Psychiatry. 1996;39:227-229.

10. Yoshimi N, Futamura T, Hashimoto K. Improvement of dizocilpine-induced social recognition deficits in mice by brexpiprazole, a novel serotonin-dopamine activity modulator. Eur Neuropsychopharmaol. 2015; 25:356-364.

11. Tandon R. Cholinergic aspects of schizophrenia. Br J Psychiatry Suppl. 1999;173:7-11.

12. Otsuka. Rexulti (brexpiprazole) Tablets for Oral Use. Prescribing information, 2015. Available from: http://www.otsuks-us.com/products/ documents/Rexulti.pdf

13. McQuade R, Hobart M, Forbes RA, et al. A phase II trial assessing the efficacy and safety of OPC-34712 in the acute treatment of schizophrenia. Poster presented at: the 24th annual US Psychiatric and Mental Health Congress; 2011; Las Vegas.
14. Correll CU, Skuban A, Ouyang J, et al. Efficacy and safety of brexpiprazole for the treatment of acute schizophrenia: a 6-week randomized, double-blind, placebo-controlled trial. Am J Psychiatry. 2015; 172:870-880.

15. Kane JM, Skuban A, Ouyang J, et al. A multi-center, randomized, double-blind, controlled phase 3 trial of fixed-dose brexpiprazole for the treatment of adults with acute schizophrenia. Schizophr Res. 2015; 164:127-135.

16. Marder SR, Skuban A, Ouyang J, et al. Efficacy of brexpiprazole on PANSS items and Marder factor scores: a meta-analysis of two pivotal studies in schizophrenia. Poster presented at: the 168th annual meeting of the American Psychiatric Association; 2015; Toronto.

17. Hobart M, Ouyang J, Forbes RA, et al. Efficacy and safety of brexpiprazole as maintenance treatment in adults with schizophrenia: a randomized, double-blind, placebo-controlled study. Poster presented at: the annual meeting of the American Society of Psychopharmacology; 2015; Miami.

18. Tandon R, Cucchiaro J, PhillipsD, etal. A double-blind, placebo-controlled, randomized, withdrawal study of lurasidone for the maintenance of efficacy in patients with schizophrenia. J Psychopharmacology. 2016; 30(1):69-77.

19. Maeda K, Lerdrup L, Sugino H, et al. Brexpiprazole II: antipsychotic and pro-cognitive effects of a novel serotonin-dopamine activity modulator. J Pharmacol Exp Ther. 2014;350:605-614.

20. Tandon R, Targum SD, Nasrallah HA, Ross R. Treatment Effectiveness in Schizophrenia Consortium. Strategies for maximizing clinical effectiveness in the treatment of schizophrenia. $J$ Psychiatr.Pract. 2006;12:348-363.

21. Thase ME, Fava M, Hobart M, et al. Efficacy of adjunctive OPC34712 across multiple outcome measures in major depressive disorder: a phase II randomized, placebo-controlled study. Neuropsychopharmacol. 2011;36:S302-S304.

22. Thase ME, Youakim JM, Skuban A, et al. Efficacy and safety of adjunctive brexpiprazole $2 \mathrm{mg}$ in major depressive disorder: a phase 3, randomized, double-blind study in patients with inadequate response to antidepressants. J Clin Psychiatry. 2015;76:1224-1231.

23. Thase ME, Youakim JM, Skuban A, et al. Adjunctive brexpiprazole 1 and $3 \mathrm{mg}$ for patients with major depressive disorder following inadequate response to antidepressants: a phase 3 , randomized, double-blind study. J Clin Psychiatry. 2015;76:1232-1240.

24. Montgomery SA, Asberg M. A new depression scale designed to be sensitive to change. Br J Psychiatry. 1979;134:382-389.

25. Berman RM, Marcus RN, Swanink R, et al. The efficacy and safety of aripiprazole as adjunctive therapy in major depressive disorder: a multicenter, randomized, double-blind, placebo-controlled study. JClin Psychiatry. 2007;68:843-853.

26. Marcus RN, McQuade RD, Carson WH, et al. The efficacy and safety of aripiprazole as adjunctive therapy in major depressive disorder: a second multicenter, randomized, double-blind, placebo-controlled study. J Clin Psychopharmacol. 2008;28:156-165.

27. El-Khalili N, Joyce M, Atkinson S, et al. Extended-release quetiapine fumarate (quetiapine XR) as adjunctive therapy in major depressive disorder (MDD) in patients with an inadequate response to ongoing antidepressant treatment: a multicenter, randomized, double-blind, placebocontrolled study. Int J Neuropsychopharmacol. 2010;13:917-932.

28. Nelson JC, Skuban A, Zhang P, et al. Long-term safety of adjunctive brexpiprazole in MDD: results from two 52-week open-label studies. Poster presented at: the 168th annual meeting of the American Psychiatric Association; 2015; Toronto. 


\section{Publish your work in this journal}

Drug Design, Development and Therapy is an international, peerreviewed open-access journal that spans the spectrum of drug design and development through to clinical applications. Clinical outcomes, patient safety, and programs for the development and effective, safe, and sustained use of medicines are a feature of the journal, which has also been accepted for indexing on PubMed Central. The manuscript management system is completely online and includes a very quick and fair peer-review system, which is all easy to use. Visit http://www.dovepress.com/testimonials.php to read real quotes from published authors.

Submit your manuscript here: http://www.dovepress.com/drug-design-development-and-therapy-journal 